\title{
Market Monitoring and Analysis: Electricity Sector
}

\author{
Helga Zogolli ${ }^{1}$
}

\begin{abstract}
EU electricity liberalisation remainsa essential energy reform programme, in scale in any other major region of the world. While other regions of the world have seen major pauses to their energy market reforms (most notably in the United States), the EU in the form of the European Commission, continues to press ahead.

Electricity market power in Albania is in a difficult situation as a consequence of the lack of the adequate home-brew electricity resources and the great dependency from the hydro resources, inadequacy of the interconnectionscapacity with the neighbouring networks of electricity power, the considerable technical and economic barriers, and the difficult financials.

In countries where no "official" power pool has been set up, different kinds of privates' entities, e.g. generators, distributors, traders, large consumers, stock exchanges, system operator etc. or a combination of them, have promoted the creation of PX-s. The idea is that because electricity is a homogeneous product, standardized contracts can be traded on organized marketplaces. Since such an initiative was not forbidden by any law or by the European Directives many project have emerged in response to different motivations.

This process in Europe, known as the liberalization process, has had a wide impact on the European electricity industry.

Electricity market liberalisation is the opening of the market to competition; the extension of vertical unbundling of transmission and distribution from the generation and retailing; and the introduction of an independent regulator.

The focus of this project is an analysis of the role of electricity PX-s in the recently liberalized electricity markets of Europe. In the context of creating "a" competitive electricity market at a European level, the key questions considered are the functioning of these PX-s with respect to electricity characteristics, market design and regulatory framework.
\end{abstract}

Keywords: Energy, 'Placing on the market", 'Eco design'," Power exchange (PX)"

\section{Introduction}

\subsection{Background}

\subsubsection{The reasons for liberalization of the electricity industry}

The motivation for electricity liberalization differs slightly between countries; however most of the countries share common ideological and political reasons regarding disaffection with the vertically integrated monopoly model of the past and a strong belief that the success of liberalization in other industries can be repeated for the electricity industry. The introduction of competition in the electricity industry has been justified by the perceived benefits of introducing market forces in an industry previously viewed as a natural monopoly with substantial vertical economies. Therefore the motivation behind 
electricity liberalization is to promote in the long run efficiency gains, to stimulate technical innovation and to lead to efficient investment.

Liberalization requires that the market is not dominated by natural monopoly characteristics. Changes in generation technologies (Hunt, 2002) and improvements in transmission (Stoft, 2002) have removed the natural monopoly character of the wholesale power market.

The case of the electricity industry is especially interesting because since the beginning of the nineteen nineties economies of scale have ceased to be the rule in the generation portion of the industry. For many years, the generation part of the electricity industry was considered to be a natural monopoly because of the economies of scale that could be obtained by using large power plants, and until the early nineteen eighties, the optimal size of generating units increased continuously. Indeed, for some fifty years the trend was for larger power plants. Then, it came new technologies like the combined cycle gas turbine and the optimal plant size for electricity generation fell dramatically. These smaller and cheaper generating units have removed the natural monopoly characteristics of generation and allowed the introduction of competition at the wholesale level. This revolutionary change has had a central and important impact on the barriers to entry in this industry, which has led to changes on its industrial organization.

Even if the changes in generation technology have reduced significantly the minimum efficient scale of generators, the improvements in information technologies with respect to transmission operation have played the most important role in creating a separate competitive wholesale market. Indeed, technological progress in aggregating physical flow and in the operation of large networks dispersed over wide geographic areas with a very high level of accuracy has played the most important role separating generation to transport.

\subsection{The liberalization process in Europe}

The objective of the European liberalization process is to open gradually electricity markets to competition to improve the general efficiency of the electricity industry, which in turn will improve the efficiency of the European economy as a whole. The electricity industry is one of the most important of Europe's industries. This sector is critical since it has an impact on all other sectors because electricity is vital for all economic activity. Hence, in a competitive world context, the competitiveness of European industry is strongly linked to the competitiveness of its electricity industry.

Liberalization of the electricity industry was part of the tools chosen by the European Community to ensure its energy policy objectives, i.e. security of supply, competitiveness and environmental protection. The origins of this approach go back to the Treaty of Rome (1957) which instituted the common market, and to the Unique Act (1986). The opening to competition of the electricity industry happened later than in other industries, where the aim was to create a single EU market by 1992 . The liberalization process really started in Europe in 1997 with the Directive 96/92/EC and the Directive 2003/54. The Directive defines common rules for the gradual liberalization of the electricity industry within the scope of the concept of a unique EU market as defined in 1985. The Directive was the result of several years of negotiation between the EU Union Member States. It defines common rules for generation, transmission and distribution of electricity. The 
stated intention of the liberalization process was not to achieve the creation of fifteen liberalized national electricity markets but one common EU electricity market as part of the EU's single market general objective.

\section{Main text:}

\section{2-1 Market Analysis}

\subsection{The European legal framework}

\subsubsection{EC Treaty}

The trading of electricity in Europe is subject to the general rules of the EC Treaty. This Treaty has been amended several times but electricity, and energy in general, has not been one of its main concerns. The origins of the EC Treaty trace back to the Treaty of Paris, which was signed in 1951, and which laid the foundations for a supranational coal regime with the establishment of the European Coal and Steel Community (ECSC). Following this Treaty, the European Atomic Energy Community (EAEC) was created with the Euratom Treaty. The ECSC and the EAEC were responsible for the common coal and nuclear policy. The European Economic Community (EC) was established in 1957 with the Treaty of Rome. The objective of the EC was to create a common market. The EC Treaty included additional provision for agriculture and transport but nothing about energy and a fortiori for electricity. The process toward a common market was accelerated in 1987 with the entry into force of the Single European Act, which amended the first three Treaties and established the objective of an internal market by the end of 1992. Finally, further amendments were made in the Treaties of Maastricht (1992) and Amsterdam (1997). In general electricity is subject to two main principles of the EC Treaty. One, electricity is subject to the rules governing the free movement of goods, persons, services and capital. Two, the electricity industry is also subject to the EC competition law, in particular those provisions related to cartel and market abuse.

The general principles of a single European "internal market", rather than many separate markets for goods and services, were established in the Single Electricity Act (EU, 1987). In this document, the single market is defined as the backbone of economic integration. The aim of the single market is to increase European economic growth by opening up national markets to competition, and thus improve overall competitiveness and raise standards of living. Following this general document, the European commission published a working document on the internal energy market (EC, 1998) which was explicitly aimed at fully integrating the separate national electricity markets throughout Europe.

The conditions for price transparency towards large electricity and gas consumers are defined in 1989, in the Directive 90/377/EC. This Directive was the first step toward the liberalization of the electricity industry. However this price transparency Directive was too weak to create competition in the electricity sector. The European Commission then decided to establish a new Directive containing stronger measures. This was done through the electricity Directive 96/92/EC and lastly through Directive 2003/54.

Directive 2005/89/EC of the European Parliament and of the Council of 18 January 2006 concerning measures to safeguard security of electricity supply and infrastructure investment. Directive 2005/89/EC establishes the guarantee of a high level of security of electricity supply is a key objective for the successful operation of the internal market 
and that Directive gives the Member States the possibility of imposing public service obligations on electricity undertakings, inter alia, in relation to security of supply. Those public service obligations should be defined as precisely and strictly as possible, and should not result in the creation of generation capacity that goes beyond what is necessary to prevent undue interruption of distribution of electricity to final customers. Directives 2009/73/EC of the European Parliament and of the Council of 21 October 2009 concerning common rules for the internal market in electricity. As regards electricity, where the roll-out of smart meters is found to be cost-effective, at least $80 \%$ of consumers must be equipped with intelligent metering systems by 2020 .

\subsubsection{The EU Directive 96/92/EC}

The EU Directive 96/92/EC (hereafter the Directive), liberalizing the electricity sectors within EU members States was agreed in 1997. The EU directive defines common rules for the generation, transmission and distribution of electricity. The Directive covers the gradual establishment of a single internal electricity market by opposition with 15 liberalized national electricity markets. First, Member States are obliged to open their national electricity market at least a minimum share of it. This means that eligible customers must be able to choose their supplier. The generation activity is totally free to promote competition as is the construction of transport lines. Finally the operation of the transmission network has to be independent from generation and distribution, at least in management terms, in order to insure transparency of the market and avoid discrimination.

The Directive removes the monopoly any incumbent may have for the construction of new power plants to promote full competition in the generation sector. The Directive gives two options for member states between, an authorization and/or tendering procedure for the construction of new generating capacity. Under the first option, member states have to define public criteria and procedures. Then companies willing to build new power plants have to go through an open and impartial procedure to decide whether they are allowed or not, to build their unit. Under the second option, a specific authority designated by the Member State defines the needs for new investments and solicits tenders. The tenders are then assessed using an impartial procedure.

In relation to transmission, each Member State must directly specify a transmission operator and the main role of the system operator is defined, i.e. generation dispatch and determination of the use of the interconnectors. This part of the Directive implies that the system operator must dispatch power plant on a nondiscriminatory basis between incumbents and new entrants. The goal of separation between generation and transport is to insure transparent and fair access to the network in order to avoid discrimination and cross-subsidization between consumers (eligible and captive).

Distribution must follow the same principles as transmission with regard to nondiscrimination. The Directive specifies that, in particular cases, the tariff to supply customers may be regulated. The important difference for distribution is that Member States may impose requirements on distribution companies in order to meet specific public service obligations.

Given the call for separation of activities, the Directive also mandates unbundling and transparency of accounts. Hence, companies with generation, transmission and 
distribution activities must present a separate balance sheet for each activity. The objective of this accounting unbundling is to avoid any cross-subsidization between different types of activity.

The central aspect of the Directive is the model of third party access. The idea is that owners of the network are obliged to allow producers and consumers to have access to their network to trade in accordance with the objectives of transparency and nondiscrimination. The Directive includes three models: negotiated third party access (nTPA), regulated third party access (rTPA), and the single buyer model. In the first model (nTPA), consumers and producers must be able to negotiate access to the network with the system operator. In the second model (rTPA), the prices for accessing to the network are regulated and not subject to negotiations. Prices must be publicly available. The system operator may refuse access to the network for technical reasons but such a refusal must be supported by a valid explanation of why access was refused. Finally, in the "single buyer model" a nominated entity acts as the only purchaser for all electricity. The Directive specifies the extent of market opening, this is defined as the percentage share of the electricity market that should be opened to competition and defines thresholds for market opening.

\subsubsection{The Directive 2003/54/EC}

On 26 June 2003, the European Commission published Directive 2003/54/EC concerning common rules for the internal market in electricity, and Regulation No 1228/2003. The Directive is required to be implemented into national law not later than 1 July 2004 and the Regulation is applicable from that date. Directive 2003/54/EC replaces Directive $96 / 92 / \mathrm{EC}$, which paved the way for liberalization of the electricity markets of European Community Member States. This Directive establishes common rules for the generation, transmission, distribution and supply of electricity. The Directive, which amend and recast the earlier electricity Directive, includes provisions for the legal unbundling of the transmission and distribution system operators, consumer protection and the establishment of independent national regulatory authorities. Moreover, the Directive aims to reduce the risk of market dominance and predatory behavior and to ensure non-discriminatory transmission and distribution tariffs and network access. Furthermore, it establishes provisions for the unbundling of transmission and distribution operators and establishes labeling requirements for electricity suppliers regarding CO2 emissions and radioactive waste from electricity production and the contribution of each energy source in a supplier's fuel mix. Also this directive, it is forecasting that the full market will be opeed by July 2007.

\subsubsection{The Directive 2005/89/EC}

On 18 January 2006, the European Commission published Directive establishes measures aimed at safeguarding security of electricity supply so as to ensure the proper functioning of the internal market for electricity and to ensure: (a) an adequate level of generation capacity; (b) an adequate balance between supply and demand; c) an appropriate level of interconnection between Member States for the development of the internal market. 2. It establishes a framework within which Member States are to define transparent, stable and non-discriminatory policies on security of electricity supply 
compatible with the requirements of a competitive internal market for electricity. This directive establishes that Member States shall establish a regulatory framework that: (a) provides investment signals for both the transmission and distribution system network operators to develop their networks in order to meet foreseeable demand from the market; and (b) facilitates maintenance and, where necessary, renewal of their networks. This directive contained :'security of electricity supply' means the ability of an electricity system to supply final customers with electricity, as provided for under this Directive; 'operational network security' means the continuous operation of the transmission and, where appropriate, the distribution network under foreseeable circumstances; 'balance between supply and demand' means the satisfaction of foreseeable demands of consumers to use electricity without the need to enforce measures to reduce consumption. Member States shall ensure a high level of security of electricity supply by taking the necessary measures to facilitate a stable investment climate and by defining the roles and responsibilities of competent authorities, including regulatory authorities where relevant, and all relevant market actors and publishing information thereon. The relevant market actors include, inter alia, transmission and distribution system operators, electricity generators, suppliers and final customers.

\subsubsection{The Directive 2009/73/EC}

On 21 October 2009 the European Commission published Directive establishes a framework for the setting of Community ecodesign requirements for energy-related products with the aim of ensuring the free movement of such products within the internal market. The ecodesign of products is a crucial factor in the Community strategy on Integrated Product Policy. As a preventive approach, designed to optimize the environmental performance of products, while maintaining their functional qualities, it provides genuine new opportunities for manufacturers, consumers and society as a whole. This Directive provides for the setting of requirements which the energy-related products covered by implementing measures must fulfil in order to be placed on the market and/or put into service. It contributes to sustainable development by increasing energy efficiency and the level of protection of the environment, while at the same time increasing the security of the energy supply.

\subsubsection{The implementation of the Directive}

The Directive was implemented into national legislation using different approaches and different paces. However the most important options of the Directive were chosen in a similar way throughout the Members States resulting in similar arrangements. In this section we focus on three major aspects of implementation of the directive: third party access, market opening and the transmission system operator.

Third party access (TPA) is one of the important points of the EU Directive. Hence it offers three ways to insure non-discriminating conditions for access to the network: regulated third party access (r'TPA), negotiated third party access (n'TPA) and the single buyer procedure. With the exception of Germany, which choose nTPA, and Portugal, and Italy who opted for the single buyer procedure, all countries have chosen rTPA. Members States have opened their market to different extents. Some countries like the UK, Germany, Sweden and Finland have opened their market at 100\%. Spain, Italy, 
Belgium, The Netherlands, Denmark and Luxembourg have opted for an opening schedule that is much more rapid than that imposed by the Directive. Finally, Greece, Ireland and France have opened their markets to meet minimum requirements.

Since the autonomy of transmission system with respect to producers was an essential condition for compliance with the obligation of transparency and nondiscriminatory access to the grid, most Members States have created an independent transmission system operator (TSO). However, the level of autonomy differs and can be differentiating in three categories: ownership, legal and management. Thus, the UK, Finland, Sweden, Spain, Denmark, Austria, the Netherlands, Portugal, Greece, and Italy have appointed a separate legal entity as the transmission system operator. Belgium, Germany, and France have appointed TSO, which are independent in management terms. In France, the TSO has management autonomy while in Germany the unbundling is limited to separate accounting.

These three aspects, third party access, market opening and unbundling represent the main criteria for implementation of the directive. The Directive grants a lot of freedom to Members States with respect to market organization. The Directive only lays down the general conditions that should be in place to assure the creation of a single electricity market but refrains from designing a concrete market organization. The Directive dictates the main principles for the development of competition through vertical separation (i.e. unbundling) of previous integrated monopolies, remove barrier to entry into production and distribution etc., but leaves each country with the freedom to decide modalities and to design their electricity markets in details. Hence, the EU Member States are radically changing the structure of their electricity industries following the Directive without strong guidelines on how to organize the details of their markets.

The second report from the Commission to the European Council and the European parliament on the state of the energy markets recognized that the directive only provided a general framework for the creation of a single market but that the creation of trade facilitating mechanisms is essential for the success of market liberalization. However no indications were given about the design of such "trade facilitating mechanisms" or for the trading of electricity in general.

\section{Case studies/application functionality}

\subsection{Market Monitoring and Analysis in Practice}

\subsubsection{Approaches to Market Monitoring Units}

Different countries have taken different approaches to the issue of how to monitor their electricity markets. Practically every country which has liberalized (very soon even Albania ${ }^{1}$ its electricity industry has an economic regulator for the industry. The economic regulator often has some overall responsibility for the state of the electricity wholesale market, but does not necessarily carry out the detailed monitoring itself. In

${ }_{1}^{1}$ Albania is one of the few countries in Europe, in which the electricity market is not yet liberalized. However, Albania Government, very lately (April 2007) has signed with World Bank, through "International Finance Corporation (IFC), the contract for the setting-up the steps of the process of the liberalization of the electricity market. This process will start with the privatization of Albanian ElectroPower Corporation (K.E.SH.), with the Distribution part of it. This process is forecasted to be finished within 2007. 
many cases, the body set up to run an electricity market was required to set up a market monitoring unit when it was established. Typically, these units are located within the market operator and have access to its data, but are given some functional independence to ensure that they cannot be captured by the operator. This might just imply direct reporting lines to the operator's board, but many monitoring units are headed, or at least supervised, by independent expert committees.

It is easiest to obtain information on market monitoring where a formal unit has been established in this way.

If a transmission operator does not have to give market-monitoring information to its regulator under a legal duty, it may still have a financial incentive to act against market power. While an independent system operator has few financial resources, and can only pass the costs of running the system through to buyers, a transmission owner may be exposed to some of these costs.

Other transmission companies may not face an explicit incentive scheme, but could find that they cannot pass cost increases straight on to consumers. In these circumstances, they also have an incentive to cooperate with regulators to combat market power that could increase system costs.

However it is organized, how a market monitor is effective. Some features can be:

- A forward-looking process can seek out small flaws in the market design or market structure before they have time to become significant market failures.

- Support from the regulator is important if the unit is more than a commentator on market events, and obtains a response to the issues that it identifies as important.

- A consistent approach will help to ensure that the market monitor's actions are understood by all market participants, and that they do not act in undesirable ways because they did not understand the likely consequences

- A transparent approach, releasing data on a timely basis (whether submitted to or produced by the market monitor) will help to promote confidence in the efficient operation of the market, and can aid the market monitoring process as well. Allowing outsiders to perform their own analyses may aid the detection of market power.

- Independence of the market monitor is the best way of avoiding the risk that its analysis would be distorted to favor one stakeholder over another.

While the details vary from market to market, the three key activities of a marketmonitoring unit are to:

- Analyze the market on a continuous basis to identify potential problems that need more study, and to screen for undesirable behavior. In some markets, this can lead to automatic real-time mitigation.

- Investigate any problems identified by its own screening, or by complaints from other stakeholders

- $\quad$ Report on the results of its analysis and investigations on a regular basis

\subsubsection{Data and Indices Tracked by Market Monitoring Divisions}

There is no universally accepted set of market monitoring statistics and indices. In practice there is a large set of data and indices that are monitored on varying time scales. The following groupings serve as a useful guide: 


\section{Market Prices and System Conditions}

The level of market prices is perhaps the most obvious thing there is to monitor. However, a moderate market price can be a sign of market abuse if it comes at a time when demand is low. This means that prices must be related to system conditions; most importantly, the level of demand, but also the level of available capacity, and indicators of transmission congestion. Although not all these measurements are directly tied to a particular index of market power, they can sometimes indicate irregularities in the market that may be symptomatic of market power problems. Furthermore, such data may also facilitate the development of other standard metrics of market power. These statistics are typically reported on a monthly, seasonal, and an annual basis, but should be collected for every period in which the market is operating.

We can differentiate between the raw data collected by the market monitor, and the statistics that are subsequently derived from them. The raw data can include:

\section{- $\quad$ Prices}

- $\quad$ Demand Conditions

- Capacity Availability

- Transmission Congestion

Given that this raw data is available, there are some statistics that can usefully be derived and monitored for signs of any problems in the market such as:

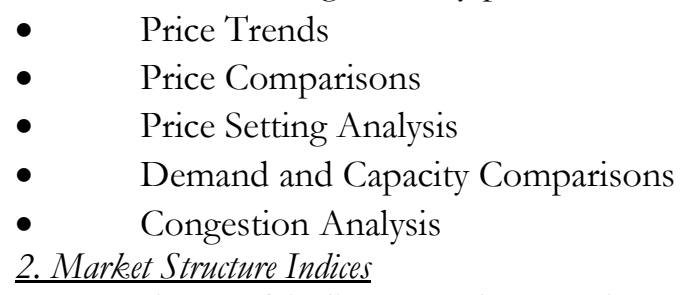

A second set of indicators relate to the market structure, underlying features of the market that will, in most cases, change only gradually. This means that some of the data need only be collected periodically, rather than on a continuous basis.

The raw data in this area consist of information on generator market shares and on the price responsiveness of demand. That information can then be analyzed to give the pivotal supplier index and residual supply index:

- Market Shares

Market shares for each company can be collected, and concentration indices can be calculated. These can be based on shares of capacity, or of output. When output shares are used, these can be collected at various frequencies, ranging from hourly to annual; monthly and daily shares are also sometimes reported.

- Hirschman-Herfindahl Indices

The market share data can also be used to calculate HHI figures, on exactly the same bases as the concentration ratios.

- Demand Responsiveness

The responsiveness of demand to changes in price affects generators' ability to exploit a large share of the supply side of the market and drive up its price.

- Pivotal Supply Analysis 
This can be performed in each of the hourly, day ahead and ancillary services markets.

- $\quad$ Residual Supply Indices

Similarly, these can be calculated for each market, including hourly, day-a-head and ancillary services.

Having calculated these indices, the market monitor can seek to establish the relationship between the market price and these measures of market competitiveness. If it is possible to establish the levels at which market performance will be broadly acceptable, then these levels can be used as a screen for analyzing merger proposals.

\section{Supplier Indices and Analysis}

The focus of supplier analysis is on the behavior of individual suppliers who might have market power. In this area, the raw data consist of bid and outage information. The first transformation may be to produce reference bids, which indicate how each unit behaves in normal conditions. These will not identify a sustained abuse of market power, but a change in conduct in response to a short-term change in circumstances will be spotted. Furthermore, it focuses on identifying the circumstances, which must make a change in behavior profitable, and checking whether the generator's behavior indeeds change in response.

- $\quad$ Market bids

The full set of bids to each organized market must be available to the market monitor, including prices, availability, and any technical constraints that are taken into account when setting prices.

\section{- $\quad$ Outages}

Data should be held on the number and duration of deratings, including the number of MW by which the unit's capacity is reduced and scheduled \& forced outages

\section{- $\quad$ Reference Bids}

These should be constructed for each market into which a unit normally bids (e.g. dayahead markets, real-time markets, and reserve markets), and can be estimated in various ways.

- Bid variation

Changes in the unit's bids, related to the abuse of market power, can be identified by:

- $\quad$ Deviation of bids from reference price levels.

- Deviation of bids from longer or shorter-term moving averages of prior bids.

- $\quad$ Frequency of re-bidding from standing orders (i.e. bids which were automatically submitted every time unless over-ridden).

\section{- Analysis of bidding}

This can include:

Correlation between bids and the level of demand

- Correlation between unit schedules or bids and the existence or magnitude of congestion.

- $\quad$ Correlation between unit schedules or bids and the market price.

- $\quad$ Comparing bid patterns between participants.

- Output analysis 
The load factor, or capacity ratio, of a generation unit is equal to its actual output divided by its maximum generation capacity multiplied by the length of the time period being considered. A falling load factor can be a sign of withholding, although it can also be a competitive response to market conditions.

- Analysis of Outages

This can include:

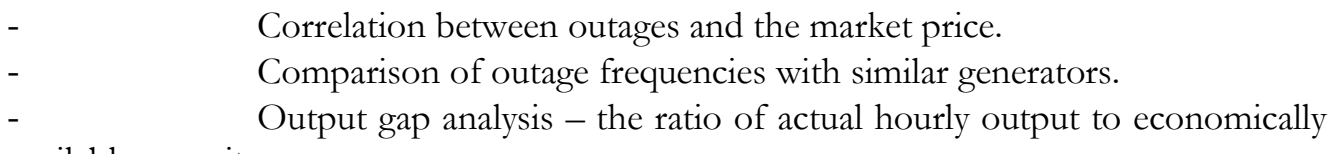
available capacity.

- $\quad$ Correlation between generators forced outages and the nodal price or congestion.

- $\quad$ Correlation between transmission facilities forced outages and the nodal price or congestion.

4. Market Performance

There are some indicators of market performance that are easily collected. Others require complicated calculations.

- Liquidity Measures

- $\quad$ The number of suppliers in short and long term markets, in particular the number of traders who don't have physical positions in the market, can indicate the level of confidence held in the market, and affects how easily a market participant can find counter-party for a trade.

- $\quad$ The volume of trade in a market, relative to the underlying physical demand, is another useful measure of liquidity

- $\quad$ Spot Market Exposure

Undue reliance on electricity spot markets is likely to lead to bad results. We can measure this by monitoring:

- The percent of load that is bought in under long term forward contracts.

- The percent of load that is supplied by insufficiently unbundled companies with no use of market mechanisms

- $\quad$ Competitive Price Benchmark Analysis

Using a suitable model, it is possible to compute a competitive price benchmark.

- $\quad$ The absolute level of this index can be an indicator of problems

- $\quad$ Comparisons can be made over time, and with other markets

- Net Revenue Analysis

This analysis is used to compare revenues with estimates of costs on a medium-term basis, typically taking a year at a time. Comparisons can be between revenues and:

- $\quad$ Entry costs (the full annualized costs of a new plant)

- $\quad$ Exit costs (costs that could avoid if a plant was to shut down for a year)

- The cost of transmission alternatives to generation.

These comparisons can be made for plant operating at a range of load factors, such as base load, intermediate and peaking plants. 
Table 1 - Summary of Market Monitoring Indices used in Practice

\begin{tabular}{|c|c|c|c|c|}
\hline & Category & Frequency & Implementation & Data Required \\
\hline \multicolumn{5}{|l|}{$\begin{array}{l}\text { Market Prices and } \\
\text { System Conditions }\end{array}$} \\
\hline Price Trends & $\begin{array}{l}\text { Close-to-real tume, } \\
\text { ex-post }\end{array}$ & $\begin{array}{l}\text { Hotsly, daily, } \\
\text { monthly }\end{array}$ & Straaghtofonward & $\begin{array}{l}\text { Spot, forward \& fiel } \\
\text { pnces }\end{array}$ \\
\hline Price Comparisons & $\begin{array}{l}\text { Close-to-teal time, } \\
\text { ex-post }\end{array}$ & $\begin{array}{l}\text { Routly, daily, } \\
\text { monthly }\end{array}$ & Strasghtforward & $\begin{array}{l}\text { Spot, forward \& fiel } \\
\text { prices }\end{array}$ \\
\hline Price Setting Analysis & Ex-post & Daily, monthly & Straightforward & $\begin{array}{l}\text { Spot, forward \& fael } \\
\text { prices }\end{array}$ \\
\hline $\begin{array}{l}\text { Demand and Capacity } \\
\text { Comparisons }\end{array}$ & Ex-post & Datly, monthly & Straightforward & $\begin{array}{l}\text { Demand data, } \\
\text { geveration capacity and } \\
\text { generation offered }\end{array}$ \\
\hline Congestion Analysis & Expost & Daily, monthly & $\begin{array}{l}\text { Considersble effort } \\
\text { required }\end{array}$ & $\begin{array}{l}\text { Transmission } \\
\text { constraints data, Nodal } \\
\text { prices or constrained } \\
\text { on off payments }\end{array}$ \\
\hline \multicolumn{5}{|l|}{ Market Structure } \\
\hline Market Share & Usually ex-ante & $\begin{array}{l}\text { Dasily, montaly. } \\
\text { anmially }\end{array}$ & $\begin{array}{l}\text { Strasghtforward but } \\
\text { requises defining } \\
\text { appropriate zove }\end{array}$ & $\begin{array}{l}\text { Generator capacity or } \\
\text { sales. Possibly } \\
\text { transmassion constraint } \\
\text { data }\end{array}$ \\
\hline HHI & Usually ex-ante & $\begin{array}{l}\text { Daily, monthly. } \\
\text { anmuzally }\end{array}$ & $\begin{array}{l}\text { Stranghtifforward but } \\
\text { requires defining } \\
\text { appropriate zone }\end{array}$ & $\begin{array}{l}\text { Generator capacity or } \\
\text { sales. Possibly } \\
\text { transmisston constraint } \\
\text { dasa }\end{array}$ \\
\hline Demand Responsiveness & $\begin{array}{l}\text { Close to real time, ex- } \\
\text { post }\end{array}$ & Mouthly, angually & Straightforward & Demand data \\
\hline Pivotal Supplier Analysis & $\begin{array}{l}\text { Ex ante, close to real } \\
\text { twoe, ex-post }\end{array}$ & Hourly, daily & $\begin{array}{l}\text { Straghtiforward but } \\
\text { requires defining } \\
\text { appropriate zooe }\end{array}$ & $\begin{array}{l}\text { Demand data and } \\
\text { generator capacity } \\
\text { Possibly transmissaca } \\
\text { constrant data }\end{array}$ \\
\hline Residual Supply Index & $\begin{array}{l}\text { Ex ante, close to real } \\
\text { time, ex-post }\end{array}$ & Hourly, daily & $\begin{array}{l}\text { Stragghtforward but } \\
\text { requises defining } \\
\text { appropriate zone }\end{array}$ & $\begin{array}{l}\text { Demand data and } \\
\text { generator capacity. } \\
\text { Possibly tranumission } \\
\text { constraint dara } \\
\end{array}$ \\
\hline \multicolumn{5}{|l|}{ Supplier Indices } \\
\hline Lerner Index & $\begin{array}{l}\text { Exa-ante, close-to-real } \\
\text { time, ex post }\end{array}$ & Dasly, monthly & $\begin{array}{l}\text { Moderate effon in using } \\
\text { cost data and congestion } \\
\text { data. }\end{array}$ & $\begin{array}{l}\text { Bid data. Possibly } \\
\text { Marginal Cost data. }\end{array}$ \\
\hline Bid Correlation Analysis & $\begin{array}{l}\text { Close-to-real time, } \\
\text { ex-post }\end{array}$ & Daily, mombly & $\begin{array}{l}\text { Moderate effort if using } \\
\text { cost data and cotagestion } \\
\text { data }\end{array}$ & $\begin{array}{l}\text { Bid data. Possibly } \\
\text { demand \& congestion } \\
\text { data }\end{array}$ \\
\hline Load Factor Analysis & $\begin{array}{l}\text { Close-to-real tume, } \\
\text { ex-post }\end{array}$ & Daily, mouthly & Straightufonward & $\begin{array}{l}\text { Output and capacity } \\
\text { daca }\end{array}$ \\
\hline Outage Analysis & Ex-post & Moathly, ansinally & Moderate effort required & $\begin{array}{l}\text { Outage data. Possably } \\
\text { demand, cost \& price } \\
\text { data. }\end{array}$ \\
\hline \multicolumn{5}{|l|}{ Market Performance } \\
\hline Liquidity Measures & $\begin{array}{l}\text { Close-to-real time, ex } \\
\text { post }\end{array}$ & Datly, monthly & Straightforward & Bid prices and volumes \\
\hline Spot Market Exposure & $\begin{array}{l}\text { Close-to-real time, ex } \\
\text { post }\end{array}$ & Daily, monthly & Straightforwand & Bid prices and volumes \\
\hline $\begin{array}{l}\text { Competitive Benchmark } \\
\text { Analysis }\end{array}$ & Ex-post & Monthly, ansusally & $\begin{array}{l}\text { Considenble effort in } \\
\text { model development }\end{array}$ & $\begin{array}{l}\text { Margunal costs, market } \\
\text { prices }\end{array}$ \\
\hline Net Revenue Analysis & Ex post & Anurally & $\begin{array}{l}\text { Considersble eflort in } \\
\text { model development }\end{array}$ & $\begin{array}{l}\text { Capital and operating } \\
\text { costs, technological data }\end{array}$ \\
\hline Simulation Models & Ex-aste & Periodic studies & $\begin{array}{l}\text { Considerable effort in } \\
\text { model development }\end{array}$ & $\begin{array}{l}\text { Cost data, demand } \\
\text { elasticities, transmassion } \\
\text { constramts }\end{array}$ \\
\hline
\end{tabular}




\section{The major conclusions from the analyses are:}

The Albanian Market Model is designed to advance the policies of the Government of Albania in the following areas:

1. Provide a framework for privatization of the electricity sector, including the privatization of the distribution functions in the near term. The framework will provide a sound basis for privatization of further segments of the sector, such as generation, as conditions warrant;

2. Move toward consistency with EU Directives and the Energy Community Treaty;

3. Minimize opportunities for informal economic activity. The Market Model thus limits the role of the OST in economic transactions to improve transparency;

4. Capture the full value of the Albanian hydro resource for the benefit of Albanian tariff customers;

5. Enhance the financial viability of the sector by clarifying responsibilities and obligations and ensuring sufficient flows of information about the operation of the market and creating a clear structure for financial transactions;

6. Ensure that tariff customers have priority in the use of the transmission system; and Provide Consumer Benefit

References

Allaz B., Vila J.L. 1993. "Cournot Competition, Forward Markets and Efficiency", Journal of Economic Theory 59, $1-16$.

Allaz, B. (1992). "Oligopoly, Uncertainty and Strategic Forward Transactions," International Journal of Industrial Organization, Vol. 10, pp. 297-308

Bower, J. July 2002, Seeking the Single European Electricity Market Evidence From an Empirical Analysis of Wholesale Market Prices (on line). (accessed 20 April, 2007) pp 1-39. Available: http://www.oxfordenergy.org/pdfs/EL01

“Ebinger, Jane. 2010. Albania’s Energy Sector : Vulnerable to Climate Change. World Bank, Washington, DC. (C) World Bank. https://openknowledge.worldbank.org/handle/10986/10161 License: CC BY 3.0 Unported.” Available:

http://web.worldbank.org/external/default/main?sortDesc=DOCD

T\&theSitePK $=301412 \&$ cntry $=82664 \&$ piPK $=51189446 \&$ page $\mathrm{PK}=51187344 \&$ menuPK $=301440$

EBRD finances private sector renewable power generation in Albania

23 November 2011 Available:

http://www.ebrd.com/news/2011/ebrd-finances-private-sector-renewable-powergeneration-in-albania-.html

EBRD Study Preliminary findings, November 2014, (on line) Available:

www.errhttp://ec.europa.eu/energy/electricity/south_east/doc/7/credit_ebrd.pdf

Elsevier Inc. July 2005, Development of the Internal Electricity Market in Europe. (on line). (Accessed on March 2007). Available:

http://www.esat.kuleuven.be/electa/publications/fulltexts/pub 1467.pdf

ETSO OPINION ON THE EVOLUTION OF THE IEM. Brussels, 30 June 2005Available:

http://www.etso-net.org/upload/documents/ETSO\%20IEM.pdf 
EC (2003) Amended proposal for a Directive amending the Electricity and Gas Directives and Amended proposal for a Regulation on cross-border exchanges in electricity (COM(2002)304final of 07/06/2002),Available:

http://europa.eu.int/comm/energy/electricity/legislation/com proposal en.htm

http://ec.europa.eu/energy/electricity/report_2006/index_en.htm

Glachant, Jean-Michel. June 28th - July 28th 2005. "Electricity Single Market in the European Union: What to do next? A discussion paper. (on line)Available:

http://www.grim.net/documents/JMG/Glachant WPsingleMarket 2005June28th.pdf

Harvey, S. and Hogan, W. (2002) "Market Power and Market Simulations", Mimeo.

Hogan, W., May 8, 2007. Acting in Time: Regulating Wholesale Electricity Markets. (on line). (Accessed May 15, 2007). Available:

http://ksghome.harvard.edu/ whogan/Hogan_FERC_050807.pdf

Hogan, W., March 2006. Reliability and scarcity pricing: Operating reserves demand Curves. (on line). (accessed on April 2007). Available:

http://www.ksg.harvard.edu/hepg/Papers/Hogan hepg 030206.pdf

Hunt S. 2002. Making Competition work, in the electricity. New York: John Wiley \& Sons, Inc.

http://eur-lex.europa.eu/legal-content/EN/TXT/?uri=celex:32012L0027

Jones, C. W. 2004. EU Energy Law, Volume 1, The Internal Energy Market, Belgium: Claeys\&Casteels

Jones, C. W., Albers, M., Cabau, E., Hancher, L., Landes, V., Woude, M.V.D. 2005. EU Energy Law, Volume 2, EU Competition Law and Energy Markets, Belgium: Claeys\&Casteels

Madlener, R., Kaufmann. M. March 2002. Power exchange spot market trading in Europe: theoretical considerations and empirical evidence (on line). (Accessed date April 2007). Available:

http://www.oscogen.ethz.ch/reports/oscogen_d5_1b_010702.pdf

OPCOM - Romanian Power Exchange -Position paper regarding "Southeast Europe Regional Electricity Market Monitoring Pilot Project Design" (on line). 16 November 2006. (accessed May 2007). Available:

http://www.naruc.org/see monitoring/docs/Romania OPCOM Response to Monito $\underline{\text { ring }}$

Republic of Albania Electricity regulatory entity board of Commissioners, Annual report ERE's activity during 2004 and conditions of electricity sector in Albania. Available:

www.erranet.org $/$ index.php? name $=$ OEeLibrary\&file $=$ download\&id $=3429 \&$ keret $=N \& s$ howheader $=\mathrm{N}-$

Recent Developments in the Romania Electricity Market (on line). (accessed May 2007). Available:http://ec.europa.eu/energy/electricity/south_east/doc/6/opcom_pres entation.pdf

Stoft, S. 2002. Power System Economics; Designing Markets for Electricity. New York:IEEE Press, WileyInterscience

Vassilopoilos, P., Sept. 2003, Models for the Identification of Market Power in Wholesale Electricity Markets (on line). (accessed March 2007). Available: http://www.dauphine.fr/cgemp/Publications/CahiersCGEMP/MemoireVassil opoulos.pdf

The Western Balkans and EU energy security

08 January 2015

The Western Balkans could boost the EU's energy security by investing in LNG terminals and new gas pipelinesAvailable:

http://www.ebrd.com/news/2015/the-western-balkans-and-eu-energy-security-.html 